J. Clin. Chem. Clin. Biochem.

Vol. 16,1978 , pp. $639-650$

\title{
Alterations of Rat Intestinal Disaccharide Absorption by Bile or Conjugated Bile Acids
}

\author{
By R. Böhmer and H. Raffler
}

Department of Clinical Chemistry, University of Ulm, Ulm, FRG

(Received January 20/August 11, 1977/April 4, 1978)

Summary: Taurocholate showed different effects on the jejunal sucrose absorption, depending on the concentration of the bile acid: $3 \mathrm{mmol} / 1$ taurocholate inhibited to a small extent $(-7 \%), 10 \mathrm{mmol} / 1$ taurocholate had no effect and $30 \mathrm{mmol} / 1$ taurocholate increased the sucrose absorption by $17 \%$. The sucrose hydrolysis was augmented by $20 \%$ in the presence of $30 \mathrm{mmol} / 1$ taurocholate. $2 \mathrm{mmol} / \mathrm{l}$ taurochenodeoxycholate caused an increase of sucrose hydrolysis (+37\%) as well as of sucrose absorption (+ $12 \%)$ in the jejunum. Pooled rat bile induced a $21 \%$ inhibition of the sucrose hydrolysis, while the sucrose absorption was unchanged. The jejunal mal tose hydrolysis was unaffected by $3 \mathrm{mmol} / 1$ taurocholate, whereas 10 or $30 \mathrm{mmol} / \mathrm{l}$ caused a minimal increase $(+3 \%)$. The absorption of the resulting glucose was reduced to $84-92 \%$. In the ileum $10 \mathrm{mmol} / \mathrm{l}$ taurocholate did not change the sucrose hydrolysis and absorption, whereas $2 \mathrm{mmol} / \mathrm{l}$ taurochenodeoxycholate induced a $30 \%$ decrease. The investigated bile acids had no effect on the microscopic structure of the small intestinal mucosa. Hypertonic solutions caused an accumulation and exfoliation of PAS-positive material at the top of the villi, independent of the presence or absence of bile acids.

\section{Änderungen der intestinalen Disaccharidabsorption der Ratte durch Galle oder konjugierte Gallensäuren}

Zusammenfassung: Taurocholat hatte -konzentrationsabhängig - unterschiedliche Effekte auf die Saccharoseabsorption im Jejunum: $3 \mathrm{mmol} / 1$ Taurocholat reduzierte sie geringfügig um 7\%, $10 \mathrm{mmol} / 1$ hatte keinen Einfluß und $30 \mathrm{mmol} / 1$ führte zu einer Steigerung um 17\%. Die Saccharosehydrolyse war bei Anwesenheit von $30 \mathrm{mmol} / 1$ Taurocholat um 20\% gesteigert. $2 \mathrm{mmol} / \mathrm{l}$ Taurochenodesoxicholat verursachte einen Anstieg sowohl der Saccharosehydrolyse $(+37 \%)$ als auch der Saccharoseabsorption $(+12 \%)$ im Jejunum. Rattengalle hemmte die Saccharosehydrolyse um 21\%, während die Saccharoseabsorption nicht beeinflußt wurde. Die Maltosehydrolyse im Jejunum wurde durch $3 \mathrm{mmol} / 1$ Taurocholat nicht verändert, während 10 oder $30 \mathrm{mmol} / 1 \mathrm{zu}$ einer minimalen Steigerung um $3 \%$ führten. Die Absorption der freigesetzen Glucose wurde auf $84-92 \%$ reduziert. Im Ileum führte $10 \mathrm{mmol} / 1$ Taurocholat zu keiner Änderung der Saccharosehydrolyse und -absorption, während $2 \mathrm{mmol} / \mathrm{l}$ Taurochenodesoxicholat eine Reduzierung um 30\% verursachte. Die untersuchten Gallensäuren führten zu keiner histologischen Veränderung der Dünndarmschleimhaut. Hypertone Perfusionslösungen riefen eine Ansammlung und Exfoliation von PAS-positivem Material an der Villusspitze hervor, unabhängig von der Anwesenheit oder Abwesenheit von Gallensäuren.

\section{Introduction}

Food digestion and absorption depend on many conditions, one of them being the composition of the intestinal contents. Bile is one factor of this "milieu interieur". Whereas some authors have investigated the influence of bile acids on monosaccharide absorption $(1-20)$, there is only one report (21) about the behaviour of disaccharide hydrolysis under the influence of taurocholate. In the present study, the effects of different bile acids and rat bile on jejunal and ileal disaccharide digestion and absorption are reported.

\section{Material and Methods}

\section{Animals}

Male gnotobiotic Wistar rats, strain R CH-bb (Thomae, Biberach, FRG), were housed in a sterilized plastic isolator, Trexler Type (Metall und Plastik, Radolfzell, FRG). The intestinal flora consisted of Lactobacillus acidophilus (ATCC 11506), Lactobacillus bifidus (isolated from human baby feces), Streptococcus faecalis (ATCC 10541), Bacteroides symbiosus (Fusobacterium symbiosum, ATCC 14940) and E. coli (isolated from rats).

The environmental conditions werc kept constant for all animals: Air temperature $24^{\circ} \mathrm{C}$, relative humidity $25-30 \%$, illumination with lights on at $7 \mathrm{a} . \mathrm{m}$. and off at $7 \mathrm{p} . \mathrm{m}$. Food 
(Altromin 1320) and water were fed to the animals ad libitum. 18 hours before starting the experiments the animals were fasted with water ad libitum. Specifications on the number and the body weight of the investigated animals as well as on the length of the perfused intestinal sections are given in the tables under "results".

\section{Chemicals}

Sodium taurocholate puriss. (Serva, Heidelberg, FRG), sodium taurochenodeoxycholate A grade (Calbiochem, Luzern, Switzerland), sucrose p. a. and $D(+)$-maltose puriss. (Serva, Heidelberg, FRG), D(-)-mannitol (Merck, Darmstadt, FRG), [U-14 C]sucrose and $\left[\mathrm{U}-{ }^{14} \mathrm{C}\right]$ maltose (Radiochemical Centre, Amersham, England), Insta-Gel (Packard Instrument, Zürich, Switzerland), phenol red (Fluka AG, Buchs, Switzerland), Glucose/Fructose testpack and Hexokinase/glucose-6-phosphate dehydrogenase testpack (Boehringer, Mannheim, FRG).

\section{Equipment}

Perfusion pump "Perfusor IV" (Braun, Melsungen, FRG), fraction collector "Ultro Rac" (LKB, Stockholm, Sweden), liquid scintillation counter "Isocab 300" (Nuclear, Chicago, USA).

\section{Perfusion technique}

The animals were taken out of the isolator and anesthetized with sodium pentobarbital (Nembutal), $60 \mathrm{mg} / \mathrm{kg}$ body weight i. p. Plastic catheters were tied into the lumen of the small intestine at the ligament of Treitz and approximately $20 \mathrm{~cm}$ distal to this point (jejunal perfusion) or $22 \mathrm{~cm}$ and approximately $2 \mathrm{~cm}$ proximal from the ileocecal valve (ileal perfusion). The perfusion system (catheters and gut segment) was quickly $(600 \mathrm{ml} / \mathrm{h})$ filled with the perfusion fluid, and then perfused at a constant rate of $12 \mathrm{ml} / \mathrm{h}$ for $60 \mathrm{~min}$. The perfusate was collected in six $10 \mathrm{~min}$ aliquots. The first sample $(0-10 \mathrm{~min}$ after starting the perfusion) was discarded because steady state conditions were not yet achieved within the first ten minutes of perfusion. The intraluminal pressure was $+4 \mathrm{~cm}$ $\mathrm{H}_{2} \mathrm{O}$ at the beginning and $-11 \mathrm{~cm} \mathrm{H}_{2} \mathrm{O}$ at the end of the perfused segment (The negative value results from the fact that the end of the leading-off catheter lay below the abdominal level). The temperature of the perfusion fluid was $25^{\circ} \mathrm{C}$ at the beginning of the perfused segment. Cooling of the animal was prevented by use of a radiation lamp. At the end of the experiment the perfused segment was removed from the animal and quickly dipped in and rinsed with icecold $\mathrm{NaCl}$-solution. Then its length was measured stretched by an attached $3.2 \mathrm{~g}$ weight.

\section{Perfusion solutions}

The stock solution of all perfusion fluids contained $\mathrm{Na}^{+}$ $147.2 \mathrm{mmol} / 1, \mathrm{~K}^{+} 4.0 \mathrm{mmol} / 1, \mathrm{Ca}^{++} 2.25 \mathrm{mmol} / 1, \mathrm{Cl}^{-}$ $155.7 \mathrm{mmol} / \mathrm{l}$ and phenol red $56.4 \mu \mathrm{mol} / \mathrm{l}(=20 \mathrm{mg} / \mathrm{l})$. The $\mathrm{pH}$ was adjusted to 6.1 . The disaccharide concentration was
$3 \mathrm{mmol} / \mathrm{l}$ of either sucrose or mal tose. Addition of $\left.\right|^{14} \mathrm{Cl}$ sucrose or $1{ }^{14} \mathrm{C} / \mathrm{mal}$ tose resulted in a radioactivity of $925 \mathrm{kBq} / \mathrm{l}(=25 \mu \mathrm{Ci} / \mathrm{l})$. The final perfusion fluids werc made by adding taurocholate $(3,10$, or $30 \mathrm{mmol} / \mathrm{l})$, taurochenodeoxycholate $(2 \mathrm{mmol} / \mathrm{l})$ or pooled rat bile from animals with a bile duct fistula. In this last-quoted case the stock perfusion fluid was mixed with one part $(v / v)$ of pooled bile so that the bile acid contents of the final perfusion solution were as follows: Total bile acids 5.6, lithocholate 0.03 , deoxycholate 0.8 , chenodeoxycholate 0.35 , ursodeoxy cholate 1.35 , cholate $3.05 \mathrm{mmol} / \mathrm{l}$. Control animals were investigated with bile acid-free perfusion fluids, the osmolalities of which had been adjusted, if necessary, to that of the bile acid containing fluids by adding mannitol. Table 1 shows which perfusion fluids were used for the perfusion of jejunal or ileal gut segments.

\section{Methods of determination and calculation}

In the native perfusion fluids and in each sample of the perfusate the ${ }^{14} \mathrm{C}$ activity was measured with a liquid scintillation counter. Because of the yellow color of the perfusate brought about by the phenol red, a quench correction was performed with the channels ratio-method (22). In the experiment performed with maltose, the glucose concentration was determined with hexokinase/glucose-6-phosphate dehydrogenase (23). In the experiments using sucrose as substrate, the concentrations of glucose and fructose in the perfusate were measured with a combined optical test with hexokinase/glucose-6-phosphate dehydrogenase and phosphoglucose isomerase (23). The phenol red content was determined according to the method of Henry (24):

In the following text all digestive-absorp tive parameters are expressed as $\mu \mathrm{mol} / \mathrm{min}$ or $\mu 1 / \mathrm{min}$, related to the total length of the perfused intestinal segment. The disaccharide absorption was defined as ${ }^{14} \mathrm{C}$ disappearance and was calculated as the amount of infused disaccharide minus the total amount of sugars recovered in the sample:

$$
A=2 \times\left(D-\frac{D \times \mathrm{cpm}_{S} \times \mathrm{EM}_{\underline{P}}}{\mathrm{cpmp}_{\mathrm{P}} \times \mathrm{EM}_{\mathrm{S}}}\right.
$$

where

$$
\begin{aligned}
\mathrm{A}= & \text { disaccharide absorption (monosaccharide } \\
& \mu \mathrm{mol} / \mathrm{min}) \\
\left(\mathrm{A}_{\mathrm{M}}=\right. & \text { maltose absorption, } \mathrm{A}_{\mathrm{S}}=\text { sucrose absorption) } \\
\mathrm{D}= & \text { amount of infused disaccharide }(\mu \mathrm{mol} / \mathrm{min} \\
& \text { disaccharide) } \\
\mathrm{cpm}_{\mathrm{P}}= & \text { counts per minute in the native perfusion fluid } \\
\mathrm{cpm}_{\mathrm{S}}= & \text { counts per minute in the sample } \\
\mathrm{EM}_{\mathrm{P}}= & \text { absorbance of the marker (phenol red) in the } \\
& \text { native perfusion fluid } \\
\mathrm{EM}_{\mathrm{S}}= & \text { absorbance of the marker (phenol red) in the sample. }
\end{aligned}
$$

\begin{tabular}{|c|c|c|c|}
\hline \multirow{2}{*}{$\begin{array}{l}\text { Substrate } \\
\text { Gut segment }\end{array}$} & Sucrose & Sucrose & \multirow{2}{*}{$\begin{array}{l}\text { Maltose } \\
\text { Jejunum }\end{array}$} \\
\hline & Jejunum & Ileum & \\
\hline Perfusion solution containing: & & & \\
\hline $\begin{array}{lr}\text { Taurocholate } 3 \mathrm{mmol} / \mathrm{l}, 295 \mathrm{mosmol} / \mathrm{kg} \\
\text { Taurocholate } 10 \mathrm{mmol} / \mathrm{l}, 302 \mathrm{mosmol} / \mathrm{kg} \\
\text { Pooled bile, } & 290 \mathrm{mosmol} / \mathrm{kg} \\
\text { Without bile acid, } & 290 \mathrm{mosmol} / \mathrm{kg}\end{array}$ & $\begin{array}{l}+ \\
+ \\
+ \\
+\end{array}$ & $\begin{array}{l}\phi \\
+ \\
\phi \\
+\end{array}$ & $\begin{array}{l}+ \\
\phi \\
\phi \\
+\end{array}$ \\
\hline $\begin{array}{l}\text { Taurocholate } 10 \mathrm{mmol} / \mathrm{l}, 332 \mathrm{mosmol} / \mathrm{kg} \\
\text { Taurocholate } 30 \mathrm{mmol} / \mathrm{l}, 335 \mathrm{mosmol} / \mathrm{kg} \\
\text { Taurochenodeoxycholate } 2 \mathrm{mmol} / \mathrm{l}, 335 \mathrm{mosmol} / \mathrm{kg} \\
\text { Without bile acid } \quad 332 \mathrm{mosmol} / \mathrm{kg}\end{array}$ & $\begin{array}{l}{ }^{\phi} \\
+ \\
+ \\
+\end{array}$ & $\begin{array}{l}\phi \\
\phi \\
+ \\
+\end{array}$ & $\begin{array}{l}+ \\
+ \\
\phi \\
+\end{array}$ \\
\hline
\end{tabular}

Tab. 1. Survey of the used perfusion solutions and the investigated gut segments. $+=$ studied, $\phi=$ not studied. 
The maltose hydrolysis (= digestion) was calculated as the sum of maltose absorption ([equ. 1]) and the amount of free glucose in the sample:

$$
H_{M}=A_{M}+\frac{0.2 \times[G]_{S} \times E M_{P}}{E M_{S}}
$$

where

$$
\begin{aligned}
H_{M} & =\text { maltose hydrolysis (glucose, } \mu \mathrm{mol} / \mathrm{min}) \\
A_{M} & =\text { see equation } 1 \\
{[G]_{S} } & =\text { glucose concentration in the sample }(\mathrm{mmol} / \mathrm{l}) .
\end{aligned}
$$

We performed two separate experimental series using sucrose as substrate. In series 1 only the sucrose absorption was measured, while in series 2 the sucrose hydrolysis was determined in addition to the sucrose absorption. The sucrose hydroly sis was calculated as follows:

$$
H_{S}=A_{S}+\frac{0.2 \times\left([G]_{S}+[F]_{S}\right) \times E M_{P}}{E M_{S}}
$$

where

$$
\begin{aligned}
& \mathrm{H}_{\mathrm{S}}=\text { sucrose hydrolysis (monosaccharide } \\
& \text { (= glucose + fructose), } \mu \mathrm{mol} / \mathrm{min} \text { ) } \\
& A_{S}=\text { see equation } 1 \\
& F_{S}=\text { fructose concentration in the sample }(\mathrm{mmol} / \mathrm{l}) \text {. }
\end{aligned}
$$

In the experiments of series 2 the results of the sucrose absorption were divided into glucose and fructose absorption:

$$
A_{G}=\frac{H_{S}}{2}-\frac{0.2 \times[G]_{S} \times E_{P}}{E M_{S}}
$$

where

$$
\begin{aligned}
& A_{G}=\text { glucose absorption }(\mu \mathrm{mol} / \mathrm{min}) \\
& \frac{\mathrm{H}_{S}}{2}: \begin{array}{l}
\text { sucrose hydrolysis (monosaccharide, } \mu \mathrm{mol} / \mathrm{min}) \\
\text { divided by factor } 2 \text { gives the amount of released } \\
\text { glucose. }
\end{array}
\end{aligned}
$$

$$
\mathbf{A}_{\mathbf{F}}=\mathbf{A}_{\mathbf{S}}-\mathbf{A}_{\mathbf{G}}
$$

where

$$
A_{F}=\text { fructose absorption }(\mu \mathrm{mol} / \mathrm{min})
$$

In order to give a quick and simple survey about a potentially different behaviour of the glucose and fructose absorption, we calculated the quotient of these two parameters $\left(A_{G} / A_{F}\right)$.

In addition to the absolute values for the glucose and fructose absorption, we calculated the relative glucose and fructose absorption:

$$
\begin{aligned}
& A_{G}(\%)=\frac{200 \times A_{G}}{H_{S}} \\
& A_{F}(\%)=\frac{200 \times A_{F}}{H_{S}}
\end{aligned}
$$

Where

$$
\begin{aligned}
A_{G}(\%) \text { and } A_{F}(\%)= & \text { glucose or fructose absorption } \\
& \text { expressed as percentage of the } \\
& \text { monosaccharide liberated during } \\
& \text { sucrose hydrolysis. }
\end{aligned}
$$

The net water movement was calculated as the difference between infused and collected volume:

$$
N W M=200=\left(200 \times \frac{E M_{P}}{E_{S}}\right)
$$

where

$$
\mathrm{NWM}=\text { net water movement }(\mu \mathrm{l} / \mathrm{min})
$$

Factor $200=$ infused volume $(\mu 1 / \mathrm{min})$.

\section{Statistical analyses}

1. Fisher's test (25) was used to examine whether there existed a linear relation between the values of the digestive-absorptive data and the perfusion time. As this linear relation could be shown in all analyses, the regression line $y=a+b x(x$-axis $=$ time axis) was calculated for each parameter in order to recognize small absorption changes with perfusion time. The regression lines of two groups were compared by Welch's method (26) or with the Student's t-test.

2. The total mean value of each digestive-absorptive parameter in each group was calculated as the sum of the single values of all fractions of all animals, divided by the number of the single values. The statistical analyses were performed with the Student's t-test or with Welch's method. All hypotheses were tested at the $5 \%$ significance level.

3. The comparisons of the body weight of the animals and of the length of the perfused segments were performed with the Student's t-test at the $5 \%$ significance level. For further details concerning the statistical analy sis see 1. c. (27).

\section{Morphological examination}

After the end of the perfusion, histologic sections from the perfused segments were fixed with Schaffer's solution and stained with hematoxylin-eosin or periodic acid-Schiff. Corresponding sections from unperfused gut segments were investigated as controls. In addition, ultrastructural examinations by transmission electron microscopy were performed in the jejunum after perfusion with an isotonic bile acid-free solution, in order to find out whether the perfusion procedure per se had any effect on the mucosal ultrastructure.

\section{Results}

With three exceptions (tables 2 and 7) the regression lines of the calculated parameters, in the presence of bile or bile acids, were parallel to those of the corresponding control group without bile or bile acids: taurocholate, taurochenodeoxycholate or rat bile in the concentrations used had no effect on the time course of the sucrose and maltose digestion and absorption. Because the statistical comparison of the regression lines gave the same results as the comparison of corresponding mean values, only the mean values are mentioned in the following text. The regression lines are summarized in the tables.

\section{Jejunum}

The maltose hydrolysis (table 2) was unaffected by $3 \mathrm{mmol} / 1$ taurocholate. With 10 or $30 \mathrm{mmol} / 1$ taurocholate the maltose hydrolysis showed a small increase $(+3 \%)$. The absorption of glucose liberated from maltose was diminished to $84-92 \%$ by taurocholate in all the concentrations used. Using an isotonic perfusion solution, the net water movement, directed from the lumen to the mucosa ("absorption"), was not changed by $3 \mathrm{mmol} / \mathrm{l}$ taurocholate. With hypertonic solutions taurocholate caused a significant reduction of the net water movement, directed from the mucosa to the lumen ("secretion"). 


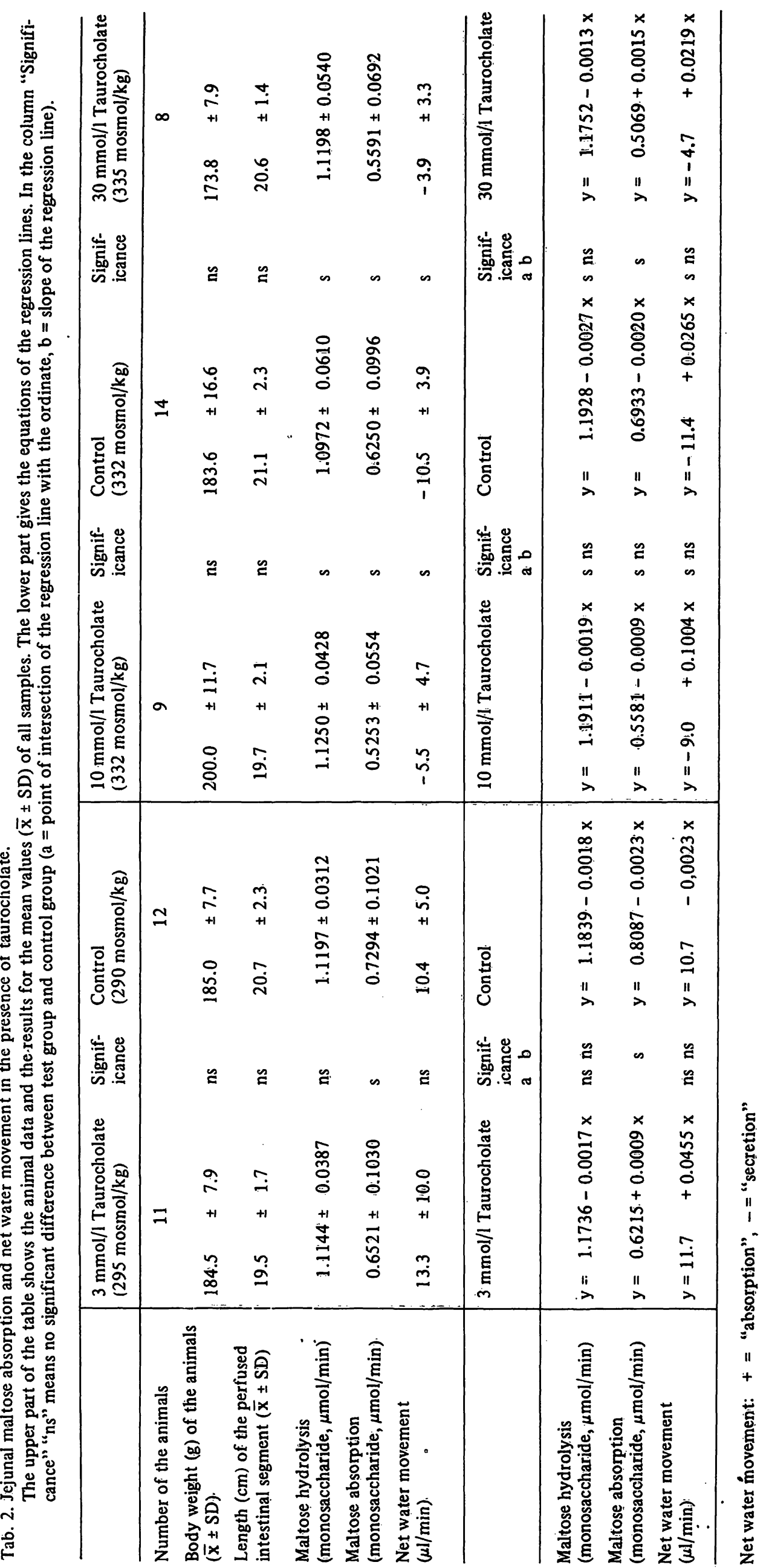


In an isotonic solution $3 \mathrm{mmol} / 1$ taurocholate reduced the jejunal sucrose absorption (table 3 ) to $93 \%$ of the control group. In the presence of $10 \mathrm{mmol} / 1$ taurocholate the sucrose absorption was unchanged. $30 \mathrm{mmol} / \mathrm{l}$ taurocholate in a hypertonic solution enhanced the sucrose absorption by $17 \%$. This effect of $30 \mathrm{mmol} / 1$ taurocholate was confirmed in the second series of the study (table 4). The increase of the sucrose absorption in the presence of $30 \mathrm{mmol} / 1$ taurocholate was the result of an enhanced fructose absorption, while the glucose absorption was unchanged: The quotient glucose/ fructose absorption was reduced from 1.57 to 1.37 . The increased sucrose absorption was accompanied by a $20 \%$ increase of the sucrose hydrolysis.

$2 \mathrm{mmol} / \mathrm{l}$ taurochenodeoxycholate (table 4 ) led to a $37 \%$ increase of the sucrose hydrolysis and a $12 \%$ increase of sucrose absorption. The absorption of the liberated glucose was unchanged, whereas the fructose absorption rose from 0.133 to $0.169 \mu \mathrm{mol} / \mathrm{min}$. The relation glucose/fructose absorption was reduced from 1.57 to 1.29 .

In the first series with sucrose as substrate (table 3 ) the net water movement ("absorption") from an isotonic solution was unaffected by $3 \mathrm{mmol} / \mathrm{l}$ taurocholate but reduced by $10 \mathrm{mmol} / \mathrm{l}$ taurocholate. Using a hypertonic solution the water "secretion" was either diminished or even converted to a water "absorption" by $30 \mathrm{mmol} / \mathrm{l}$ taurocholate. $2 \mathrm{mmol} / 1$ taurochenodeoxycholate caused a reduction of the water "secretion".

The addition of rat bile to the perfusion fluid (table 5) led to a $21 \%$ decrease of the sucrose hydrolysis. The changes in the absorption of the split products, glucose and fructose, were not statistically significant, but the relation of glucose/fructose absorption was significantly reduced from 1.92 to 1.68 .

\section{Ileum}

$10 \mathrm{mmol} / \mathrm{l}$ taurocholate in an isotonic solution (tables 6 and 7) had no effect on the sucrose hydrolysis, the absorption of the split products or the net water movement. The ratio glucose/fructose absorption was also unchanged.

With $2 \mathrm{mmol} / \mathrm{l}$ taurochenodeoxycholate the sucrose hydrolysis was decreased by $30 \%$ and the sucrose absorption by $33 \%$. The reduction of the sucrose absorption was the consequence of a diminution of the glucose absorption $(-36 \%)$ as well as of the fructose absorption $(-28 \%)$. The net water movement ("absorption") was diminished by $70 \%$.

No histological changes were detectable in the jejunum and in the ileum after perfusion with isotonic solutions, irrespective of the presence or absence of bile acids. The ultrastructural picture of the jejunal mucosa also remained unaffected by an isotonic, bile acid-free perfusion fluid. Perfusion with hypertonic solutions caused an increased exfoliation of cells at the top of the villi and an accumulation of PAS-positive material at this site (Fig. 1). This effect was independent of the presence or absence of bile acids.

\section{Discussion}

Except for one study by our group (21), in which we found a decreased jejunal lactose hydrolysis in the presence of $8 \mathrm{mmol} / \mathrm{l}$ taurocholate, there are no reports in the literature concerning the dependence of disaccharide hydrolysis and absorption on bile acids in the intestinal contents. In the present study the influence of taurocholate on the jejunal sucrose absorption was concentration-dependent: $3 \mathrm{mmol} / 1$ taurocholate reduced the sucrose absorption to a small extent, $10 \mathrm{mmol} / 1$ taurocholate hat no effect, and $30 \mathrm{mmol} / \mathrm{l}$ taurocholate caused in increased sucrose absorption. Since the total luminal bile acid concentration in the upper jejunum of the rat amounts to $5-10 \mathrm{mmol} / 1$ $(28,29)$, and since taurocholate makes up one third to one fourth of this quantity (30), a taurocholate concentration of $3 \mathrm{mmol} / \mathrm{l}$ comes nearest to the physiological concentration.

The calculation of the sucrose absorption by measuring the ${ }^{14} \mathrm{C}$ disappearance gives no information about the specific behaviour of the glucose and fructose absorption. For example, the total sucrose absorption can be unchanged in spite of a decreased glucose absorption, if this diminution is compensated by an increased fructose absorption. For this reason the increased sucrose absorption in the presence of $30 \mathrm{mmol} / 1$ taurocholate was further scrutinized by a separate determination of the glucose and fructose absorption. In this special case it could be shown that the glucose absorption was unchanged, whereas the fructose absorption was enhanced. The quotient glucose/fructose absorption fell from 1.57 in the control group to 1.37 in the presence of taurocholate. The increased fructose disappearance rate was accompanied by an enhanced sucrose hydrolysis. Since the absorption of the liberated glucose was not altered, the stimulation of the fructose absorption might have been the consequence of an increased glucose concentration. This hypothesis is in accordance with the findings of Holdsworth \& Dawson (31), who showed an augmented fructose absorption in the presence of glucose.

The maltose hydrolysis was not altered by $3 \mathrm{mmol} / \mathrm{l}$ taurocholate, but it was increased by $10 \mathrm{mmol} / 1$ taurocholate. An increased disaccharide hydrolysis is not necessarily accompanied by an increased disaccharide absorption. In the experiments performed with maltose, $30 \mathrm{mmol} / \mathrm{l}$ taurocholate led to an augmented disaccharide hydrolysis, but the absorption of the liberated glucose was diminished. A diminished glucose absorption could also be demonstrated at lower taurocholate concentrations ( 3 or $10 \mathrm{mmol} / \mathrm{l})$. The inhibitory effect of taurocholate on the absorption of glucose, liberated from 


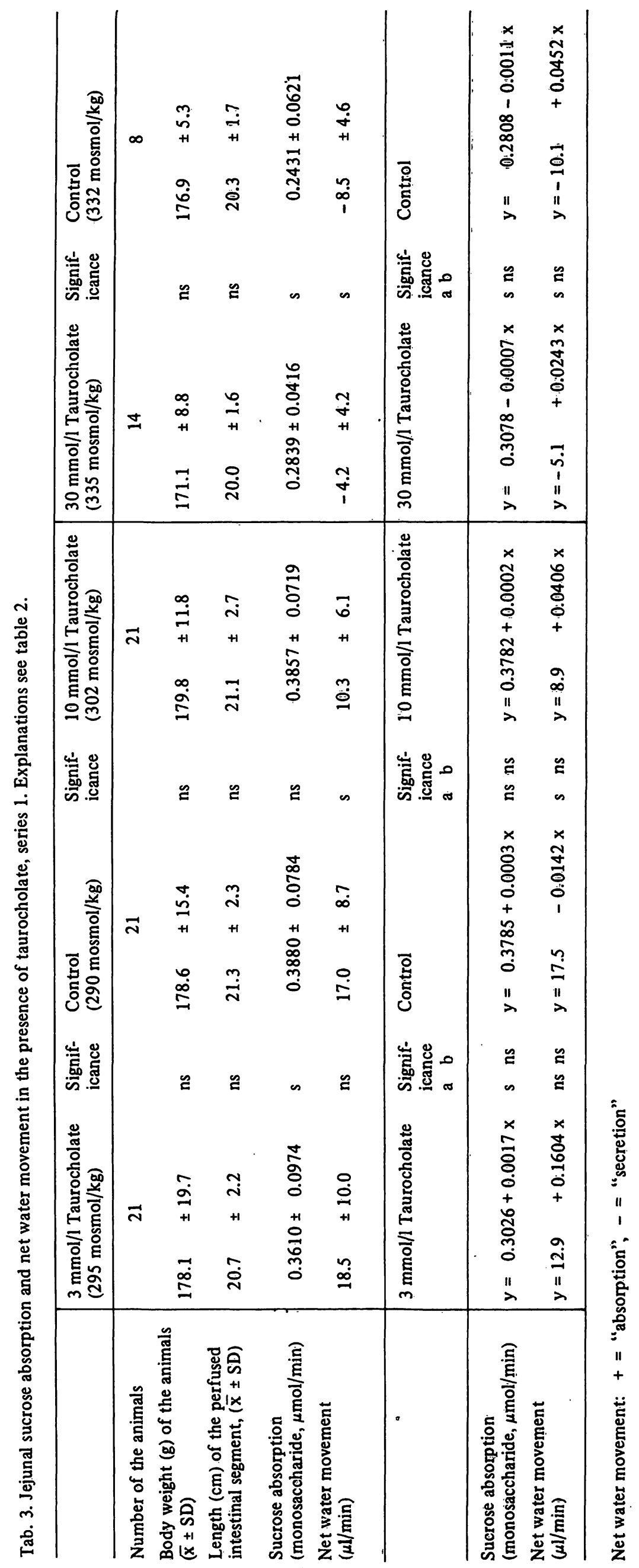

J. Clin. Chem. Clin. Biochem. / Vol. 16, 1978 / No. 12 
Tab. 4. Jejunal sucrose absorption and net water movement in the presence of taurocholate (series 2) and taurochenodeoxycholate. Explanations see table 2.

\begin{tabular}{|c|c|c|c|c|c|c|c|c|c|c|}
\hline \multirow{3}{*}{$\begin{array}{l}\text { Number of the animals } \\
\text { Body weight }(g) \text { of the animals } \\
(\bar{x} \pm \text { SD) }\end{array}$} & \multicolumn{2}{|c|}{$\begin{array}{l}2 \mathrm{mmol} / \mathrm{l} \\
\text { Taurochenodeoxycholate } \\
\text { (335 mosmol } / \mathrm{kg} \text { ) }\end{array}$} & \multicolumn{2}{|c|}{$\begin{array}{l}\text { Signif- } \\
\text { icance }\end{array}$} & \multicolumn{2}{|c|}{$\begin{array}{l}\text { Control } \\
(332 \mathrm{mosmol} / \mathrm{kg})\end{array}$} & \multicolumn{2}{|c|}{$\begin{array}{l}\text { Signif- } \\
\text { icance }\end{array}$} & \multicolumn{2}{|c|}{$\begin{array}{l}30 \mathrm{mmol} / \mathrm{l} \\
\text { Taurocholate } \\
\text { ( } 335 \mathrm{mosmol} / \mathrm{kg})\end{array}$} \\
\hline & & 4 & & & & 6 & & & & 6 \\
\hline & 182.5 & \pm 9.6 & ns & & 183.7 & \pm 4.3 & ns & & 190.2 & \pm 5.9 \\
\hline $\begin{array}{l}\text { Length }(\mathrm{cm}) \text { of the perfused } \\
\text { intestinal segment, }(\bar{x} \pm S D)\end{array}$ & 20.5 & \pm 1.5 & ns & & 19.8 & \pm 1.4 & ns & & 21.2 & \pm 1.0 \\
\hline $\begin{array}{l}\text { Sucrose hydrolysis } \\
\text { (monosaccharide, } \mu \mathrm{mol} / \mathrm{min} \text { ) }\end{array}$ & \multicolumn{2}{|c|}{$0.7615 \pm 0.1398$} & \multicolumn{2}{|l|}{$\mathbf{s}$} & \multicolumn{2}{|c|}{$0.5565 \pm 0.1061$} & \multicolumn{2}{|l|}{$s$} & \multicolumn{2}{|c|}{$0.6703 \pm 0.0854$} \\
\hline $\begin{array}{l}\text { Sucrose absorption } \\
\text { (monosaccharide, } \mu \mathrm{mol} / \mathrm{min} \text { ) }\end{array}$ & \multicolumn{2}{|c|}{$0.3834 \pm 0.0560$} & $\mathbf{s}$ & & \multicolumn{2}{|c|}{$0.3411 \pm 0.0568$} & \multicolumn{2}{|l|}{$\mathbf{s}$} & \multicolumn{2}{|c|}{$0.3915 \pm 0.0758$} \\
\hline $\begin{array}{l}\text { Sucrose absorption } \\
\text { (\% of sucrose hydrolysis) }\end{array}$ & 52 & \pm 11 & & & 62 & \pm 5 & & & 58 & \pm 7 \\
\hline $\begin{array}{l}\text { Glucose absorption } \\
\text { (umol/min) }\end{array}$ & \multicolumn{2}{|c|}{$0.2151 \pm 0.0321$} & \multicolumn{2}{|l|}{ ns } & \multicolumn{2}{|c|}{$0.2077 \pm 0.0340$} & \multicolumn{2}{|l|}{ ns } & \multicolumn{2}{|c|}{$0.2245 \pm 0.0414$} \\
\hline $\begin{array}{l}\text { Glucose absorption } \\
\text { (\% of liberated glucose) }\end{array}$ & 58 & \pm 12 & & & 76 & \pm 7 & & & 67 & \pm 8 \\
\hline $\begin{array}{l}\text { Fructose absorption } \\
(\mu \mathrm{mol} / \mathrm{min})\end{array}$ & \multicolumn{2}{|c|}{$0.1685 \pm 0.0287$} & \multicolumn{2}{|l|}{$\mathbf{s}$} & \multicolumn{2}{|c|}{$0.1334 \pm 0.0238$} & \multicolumn{2}{|l|}{$\mathbf{s}$} & \multicolumn{2}{|c|}{$0.1669 \pm 0.0373$} \\
\hline $\begin{array}{l}\text { Fructose absorption } \\
\text { (\% of liberated fructose) }\end{array}$ & & \pm 12 & & & 48 & \pm 4 & & & 50 & \pm 7 \\
\hline $\begin{array}{l}\text { Quotient glucose/fructose } \\
\text { absorption }\end{array}$ & 1.290 & \pm 0.153 & $\mathbf{s}$ & & 1.565 & \pm 0.103 & $s$ & & 1.366 & \pm 0.148 \\
\hline \multirow[t]{2}{*}{$\begin{array}{l}\text { Net water movement } \\
(\mu \mathrm{l} / \mathrm{min})\end{array}$} & -2.0 & \pm 5.5 & s & & -6.7 & \pm 5.0 & $s$ & & 6.1 & \pm 5.9 \\
\hline & $\begin{array}{l}2 \mathrm{mmol} / \mathrm{l} \\
\text { Taurocher }\end{array}$ & nodeoxycholate & & $\begin{array}{l}\text { gnif- } \\
\text { ance } \\
b\end{array}$ & Control & & & $\begin{array}{l}\text { nif- } \\
\text { nce } \\
\text { b }\end{array}$ & $\begin{array}{l}30 \mathrm{mmo} \\
\text { Tauroch }\end{array}$ & llate \\
\hline $\begin{array}{l}\text { Sucrose hydrolysis } \\
\text { (monosaccharide, } \mu \mathrm{mol} / \mathrm{min} \text { ) }\end{array}$ & \multicolumn{2}{|c|}{$y=0.9135-0.0043 x$} & & ns & $y=0.7$ & $401-0.0052 x$ & $s$ & ns & \multicolumn{2}{|c|}{$y=0.8840-0.0061 x$} \\
\hline $\begin{array}{l}\text { Sucrose absorption } \\
\text { (monosaccharide, } \mu \mathrm{mol} / \mathrm{min} \text { ) }\end{array}$ & \multicolumn{2}{|c|}{$y=0.4305-0.0013 x$} & $s$ & ns & $y=0.4$ & $268-0.0024 x$ & $\mathbf{s}$ & ns & \multicolumn{2}{|c|}{$y=0.4879-0.0028 x$} \\
\hline $\begin{array}{l}\text { Glucose absorption } \\
(\mu \mathrm{mol} / \mathrm{min})\end{array}$ & \multicolumn{2}{|c|}{$y=0.2491-0.0010 x$} & ns & ns & $y=$ & $587-0.0015 x$ & ns & ns & \multicolumn{2}{|c|}{$y=0.2822-0.0016 x$} \\
\hline $\begin{array}{l}\text { Fructose absorption } \\
(\mu \mathrm{mol} / \mathrm{min})\end{array}$ & \multicolumn{2}{|c|}{$y=0.1815-0.0004 x$} & $\mathbf{s}$ & ns & $y=$ & $684-0.0010 x$ & $\mathbf{s}$ & ns & \multicolumn{2}{|c|}{$y=0.2056-0.0011 x$} \\
\hline $\begin{array}{l}\text { Quotient glucose/fructose } \\
\text { absorption }\end{array}$ & $y=1.382$ & $-0.0030 x$ & s & ns & $y=1.5$ & $36+0.0010 x$ & $\mathbf{s}$ & ns & $y=1.37$ & \\
\hline $\begin{array}{l}\text { Net water movement } \\
(\mu \mathrm{l} / \mathrm{min}\end{array}$ & $y=$ & $0-0.0587 x$ & $\mathbf{s}$ & ns & $y=-7.0$ & $+0.0087 x$ & $\mathbf{s}$ & ns & $y=3.1$ & $+0.0888 x$ \\
\hline
\end{tabular}

Net water movement: + = "absorption", - = "secretion"

maltose, was most pronounced at the beginning of the intestinal perfusion. 60 minutes after starting the experiment, the glucose absorption was in the same range as that in the absence of taurocholate.

The distinct influence of $30 \mathrm{mmol} / \mathrm{l}$ taurocholate on the absorption of glucose, liberated from either sucrose or maltose, may be explained by different effects of taurocholate on the special transport systems, which are responsible for the absorption of monosaccharides resulting from disaccharides (32-35). Besidẹs different effects of taurocholate on the sucrase- and maltase- related transport systems, an effect of the glucose concentration at the site of absorption must also be considered: The glucose concentration is higher during perfusion with maltose than with sucrose, as the maltase activity is greater than the sucrase activity. In addition, sucrose hydrolysis liberates one glucose molecule from one sucrose molecule, whereas two glucose molecules originate from one maltose molecule. Perhaps the inhibitory effect of $30 \mathrm{mmol} / \mathrm{l}$ taurocholate on the glucose absorption occurs only with higher glucose concentrations. 
Tab. 5. Jejunal sucrose absorption and net water movement in the presence of bile. Explanations see table 2.

\begin{tabular}{|c|c|c|c|c|}
\hline & $\begin{array}{l}\text { Pooled rat bile } \\
(290 \mathrm{mosmol} / \mathrm{kg})\end{array}$ & Significance & \multicolumn{2}{|c|}{$\begin{array}{l}\text { Control } \\
(290 \mathrm{mosmol} / \mathrm{kg})\end{array}$} \\
\hline Number of the animals & 8 & & & 8 \\
\hline Body weight $(g)$ of the animals $(\bar{x} \pm S D)$ & \pm 10.3 & ns & 182.5 & \pm 9.2 \\
\hline $\begin{array}{l}\text { Length }(\mathrm{cm}) \text { of the perfused intestinal } \\
\text { segment }(\overline{\mathrm{x}} \pm S D)\end{array}$ & $20.1 \pm 2.8$ & ns & 19.1 & \pm 0.9 \\
\hline $\begin{array}{l}\text { Sucrose hydrolysis } \\
\text { (monosaccharide, } \mu \mathrm{mol} / \mathrm{min} \text { ) }\end{array}$ & $0.6230 \pm 0.0906$ & $\mathbf{s}$ & \multicolumn{2}{|c|}{$0.7889 \pm 0.1477$} \\
\hline $\begin{array}{l}\text { Sucrose absorption } \\
\text { (monosaccharide, } \mu \mathrm{mol} / \mathrm{min} \text { ) }\end{array}$ & $0.3694 \pm 0.0501$ & \multirow[t]{2}{*}{ ns } & \multicolumn{2}{|c|}{$0.3714 \pm 0.0824$} \\
\hline Sucrose absorption (\% of sucrose hydrolysis) & \pm 4 & & 47. & \pm 7 \\
\hline Glucose absorption $(\mu \mathrm{mol} / \mathrm{min})$ & $0.2303 \pm 0.0309$ & ns & \multicolumn{2}{|c|}{$0.2423 \pm 0.0521$} \\
\hline $\begin{array}{l}\text { Glucose absorption } \\
\text { (\% of liberated glucose) }\end{array}$ & & & 62 & \pm 9 \\
\hline Fructose absorption ( $\mu \mathrm{mol} / \mathrm{min})$ & $0.1391 \pm 0.0273$ & ns & \multicolumn{2}{|c|}{$0.1292 \pm 0.0340$} \\
\hline $\begin{array}{l}\text { Fructose absorption } \\
\text { (\% of liberated fructose) }\end{array}$ & \pm 5 & & 33 & \pm 6 \\
\hline Quotient glucose/fructose absorption & $1.682 \pm 0.173$ & s & 1.924 & \pm 0.286 \\
\hline \multirow[t]{2}{*}{ Net water movement $(\mu \mathrm{l} / \mathrm{min})$} & $11.0 \pm 5.4$ & ns & 10.3 & \pm 6.2 \\
\hline & Pooled rat bile & $\begin{array}{l}\text { Significance } \\
a \quad b\end{array}$ & Control & \\
\hline $\begin{array}{l}\text { Sucrose hydrolysis } \\
\text { (monosaccharide, } \mu \mathrm{mol} / \mathrm{min} \text { ) }\end{array}$ & $y=0.7278-0.0029 x$ & s ns & \multicolumn{2}{|c|}{$y=0.9711-0.0029 x$} \\
\hline $\begin{array}{l}\text { Sucrose absorption } \\
\text { (monosacharide, } \mu \mathrm{mol} / \mathrm{min} \text { ) }\end{array}$ & $y=0.3877-0.0005 x$ & ns ns & $y=0.37$ & $63-0.0001 x$ \\
\hline Glucose absorption $(\mu \mathrm{mol} / \mathrm{min})$ & $y=0.2393-0.0003 x$ & ns ns & $y=0.24$ & \\
\hline Fructose absorption ( $\mu \mathrm{mol} / \mathrm{min})$ & $y=0.1484-0.0003 x$ & ns ns & $y=0.13$ & $45-0.0002 x$ \\
\hline Quotient glucose/fructose absorption & $y=1.610+0.0020 x$ & s ns & $y=1.86$ & $0+0.0020 x$ \\
\hline Net water movement $(\mu 1 / \mathrm{min})$ & $y=7.8+0.0903 x$ & ns ns & $y=8.2$ & $+0.0596 x$ \\
\hline
\end{tabular}

Net water movement: + = "absorption", - = "secretion"

Tab. 6. Ileal sucrose absorption and net water movement in the presence of taurocholate, series 1. Explanations see tab. 2.

\begin{tabular}{|c|c|c|c|c|}
\hline & $\begin{array}{l}10 \mathrm{mmol} / 1 \text { Taurocholate } \\
(302 \mathrm{mosmol} / \mathrm{kg})\end{array}$ & Significance & \multicolumn{2}{|c|}{$\begin{array}{l}\text { Control } \\
(290 \mathrm{mosmol} / \mathrm{kg})\end{array}$} \\
\hline Number of the animals & 8 & & & 8 \\
\hline Body weight $(g)$ of the animals $(\bar{x} \pm S D)$ & $262.5 \pm 9.6$ & ns & 260.6 & \pm 17.8 \\
\hline $\begin{array}{l}\text { Length }(\mathrm{cm}) \text { of the perfused intestinal } \\
\text { segment }(\bar{x} \pm S D)\end{array}$ & $20.7 \quad \pm 3.3$ & ns & $20: 8=$ & \pm 1.6 \\
\hline $\begin{array}{l}\text { Sucrose absorption } \\
\text { (monosaccharide, } \mu \mathrm{mol} / \mathrm{min} \text { ) }\end{array}$ & $0.1495 \pm 0.0602$ & ns & 0.1628 & \pm 0.0485 \\
\hline Net water movement $(\mu 1 / \min )$ & $\begin{array}{c}15.3 \quad \pm 5.2 \\
\ldots\end{array}$ & ns & $13.4 \pm$ & \pm 6.1 \\
\hline · & $10 \mathrm{mmol} / 1$ Taurocholate & $\begin{array}{l}\text { Significance } \\
\mathrm{a} \mathrm{b}\end{array}$ & Control & \\
\hline $\begin{array}{l}\text { Sucrose absorption } \\
\text { (monosaccharide, } \mu \mathrm{mol} / \mathrm{min} \text { ) }\end{array}$ & $y=0.1931-0.0012 x$ & ns ns & $y=0.1537$ & $7+0.0003 x$ \\
\hline Net water movement $(\mu \mathrm{l} / \mathrm{min})$ & $y=13.4+0.0550 x$ & ns ns & $y=6.8$ & $+0.1948 x$ \\
\hline
\end{tabular}

Net water movement: + = "absorption", - = "secretion" 


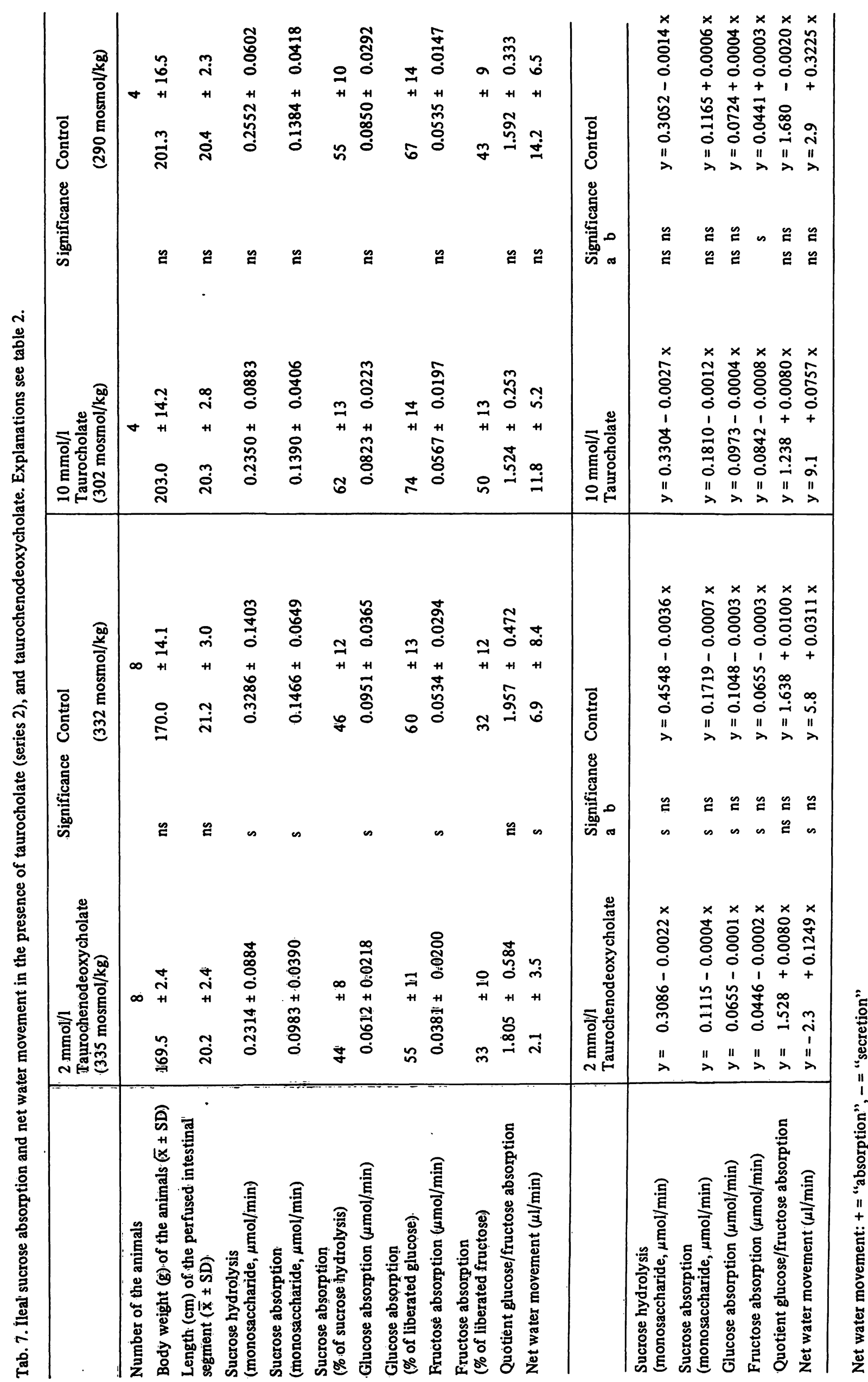



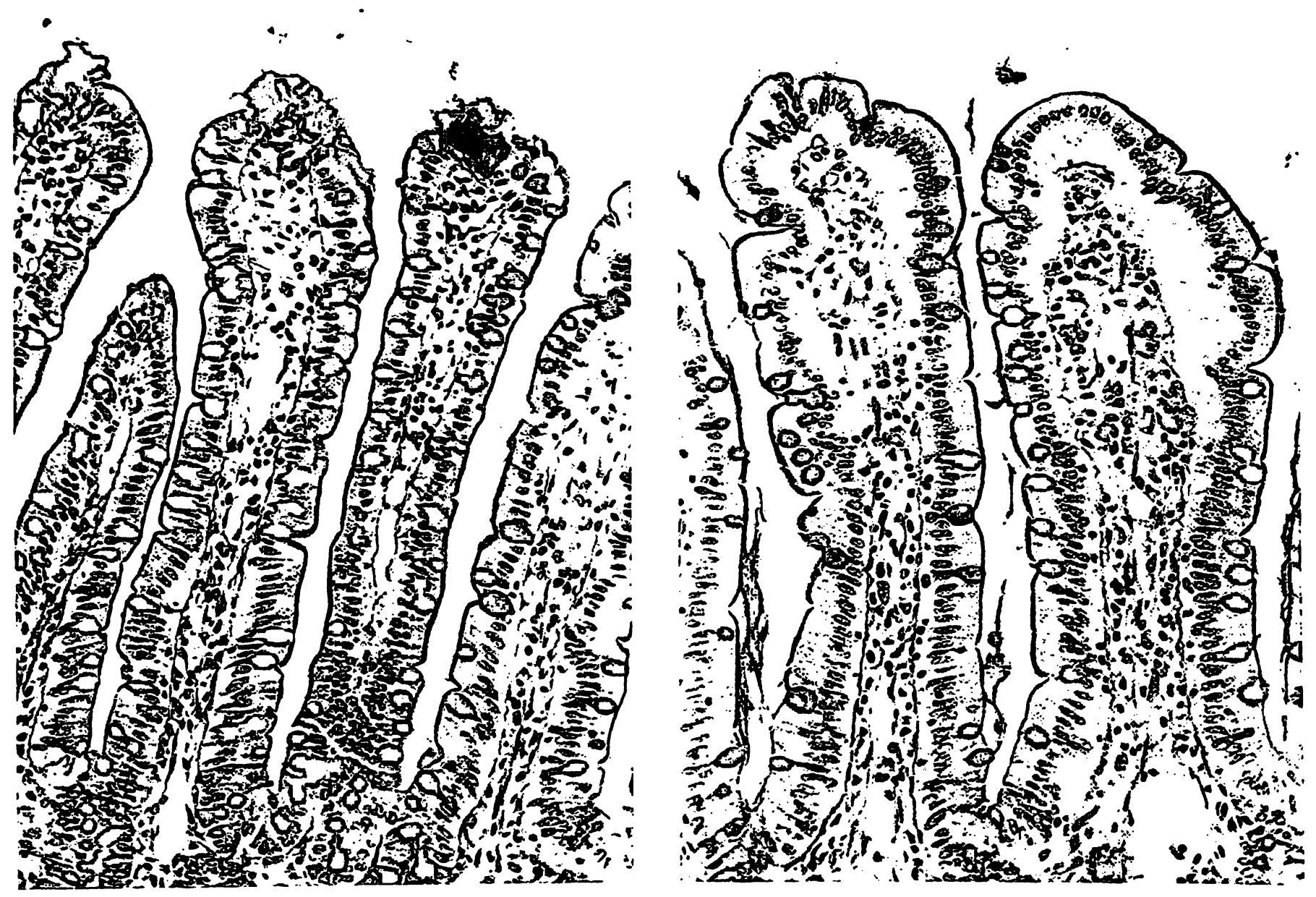

Fig. 1. Accumulation of PAS-positive material at the top of the villi and increased exfoliation of cells at this site after perfusion with hypertonic solutions (left side). Unchanged mucosal structure af ter perfusion with isotonic solutions (right side) (PAS, $\times 200$ ).

$2 \mathrm{mmol} / \mathrm{l}$ taurochenodeoxycholate enhanced the sucrose hydrolysis and the sucrose absorption in the jejunum. The increased sucrose absorption was the result of an augmented fructose absorption while the glucose absorption was unchanged.

In the experiments performed with pooled rat bile, a physiological bile acid concentration $(5.6 \mathrm{mmol} / \mathrm{l})$ was established. The presence of bile inhibited the sucrose hydrolysis, whereas the sucrose absorption was not altered: The glucose absorption was reduced, and the fructose absorption was enhanced in the same degree, so that the sum of both remained constant. The quotient glucose/fructose absorption was reduced.

The ileum is the site of active bile acid absorption. This active transport is not inhibited by glucose (28). Ön the other hand, the ileal sugar absorption may be altered by bile acids: In vitro-experiments in the rat showed inhibitory effects of taurocholate and glycocholate on the ileal monosaccharide absorption $(1,17)$. The absorption of monosaccharides liberated from sucrose or maltose was also diminished in spite of an unchanged disaccharide hydrolysis (1). In contrast to these results, our experiments showed that $10 \mathrm{mmol} / 1$ taurocholate had no effect on the hydrolysis of sucrose and the absorption of its split products. An explanation for the partial discordance of our results, compared to the data in the literature, may be given by the different experimental designs: The inhibitory effects of taurocholate and glycocholate on the absorption of free monosaccharides $(1,17)$ and of monosaccharides, liberated from disaccharides (1), were proved by in vitro-techniques, whereas in the present investigation in vivo-techniques were used. In man, the ileal monosaccharide absorption was not altered by glycocholate (20).

$2 \mathrm{mmol} / \mathrm{l}$ taurochenodeoxycholate caused a decreased sucrose hydrolysis and absorption. The relation glucose/ fructose absorption remained unchanged. It must be considered whether this inhibitory effect of taurochenodeoxycholate on the ileal absorption of glucose and fructose was caused by a diminished offer of these monosaccharides as a consequence of the decreased sucrose hydrolysis. The rate limiting factor for disaccharide absorption is not the hydrolysis of the disaccharide but the absorption of the split products (36): 
In all our experiments unabsorbed monosaccharides could be found in the perfusate. On the premise that only the ileal sucrose hydrolysis was diminished by taurochenodeoxycholate with unchanged function of the monosaccharide transport systems, the relative monosaccharide absorption, i. e. the absorption expressed as a percentage of the liberated monosaccharide, should have been increased. In reality, the relative monosaccharide absorption was unchanged (table 7), so that an inhibition of the glucose and fructose transport systems in addition to a diminished sucrose hydrolysis must be postulated. Gray \& Ingelfinger (37) described a smaller sucrose hydrolysis in the ileum than in the jejunum of man. Moreover, these authors could prove that in comparison to the situation in the jejunum, the absorption of the split products in the ileum was even more diminished than the disaccharide hydrolysis. These results in man where confirmed in the rat by the present results: The sucrose hydrolysis in the ileum amounted to $59 \%$ of that in the jejunum. The relative absorption of the sucrose split products was $76 \%$ (glucose) and $48 \%$ (fructose) in the jejunum and $60 \%$ (glucose) and $32 \%$ (fructose) in the ileum.

The results for the net water movement showed a great interindividual scattering within each experimental group of animals. In an isotonic solution $3 \mathrm{mmol} / \mathrm{l}$ taurocholate had no effect on the jejunal net water movement ("absorption"), whereas $10 \mathrm{mmol} / \mathrm{l}$ caused a decreased water absorption. A similar concentration-dependent effect of taurocholate on the jejunal water absorption was described in the hamster (2). In in vivo-experiments in the rat $5 \mathrm{mmol} / 1$ taurocholate inhibited (18) or did not alter (8) the jejunal water transport. In our experiments, the application of a hypertonic bile acid-free perfusion fluid caused a net water movement from the tissue to the lumen ("secretion") of the jejunum. This secretion was inhibited by $10 \mathrm{mmol} / 1$ or $30 \mathrm{mmol} / 1$ taurocholate as well as by $2 \mathrm{mmol} / \mathrm{l}$ taurochenodeoxycholate. From these results we conclude that the effect of taurocholate on the jejunal water transport not only depended on the bile acid concentration but also on the osmolality of the perfusion fluid. Pooled rat bile in an isotonic solution had no effect on the jejunal net water movement.

In the ileum $10 \mathrm{mmol} / \mathrm{l}$ taurocholate in an isotonic solution did not alter the net water movement. This result is in accordance with those of other authors who found no effect of bile or taurocholate up to a concentration of $20 \mathrm{mmol} / \mathrm{l}(18)$. In man $5 \mathrm{mmol} / \mathrm{l}$ glycocholate or cholate had also no effect (20). $2 \mathrm{mmol} / 1$ taurochenodeoxycholate in a hypertonic solution caused a significant reduction of the ileal water absorption.

No histological alterations of the small intestinal mucosa could be shown after perfusion with isotonic solutions, either containing bile acids or not. In the literature there are also some reports that conjugated bile acids do not cause any morphological changes of the gut mucosa (15, 38,39 ). In contrast, epithelial defects brought about by unconjugated bile acids have been described $(14,15$, 38,39 ). The morphological changes at the top of the villi after perfusion with hypertonic solutions were obviously caused by the hypertonicity of the perfusion solution. A bile acid-specific effect is unlikely, for these alterations were also found after perfusion with hypertonic bile acid-free solutions. The accumulation of PASpositive material at the top of the villi and the exfoliation at this site may be explained by two different processes: The accumulation of PAS-positive material at the top of the villi suggests a delayed discharge of the goblet cell mucus. An increased number of goblet cells at the top of the villi seems unlikely because of the short duration of the experiment $(60 \mathrm{~min})$. The exfoliation of cells may be the consequence of damage of the epithelial layer. Recently, ultra-structural changes of the intestinal absorptive cells have been described after perfusion with hypertonic glucose solutions (40).

\section{Acknowledgement}

This work was supported by the Deutsche Forschungsgemeinschaft, Bad Godesberg, Sonderforschungsbereich 112, Projekt E4.

We thank Prof. Dr. W. Mohr, Division of Pathology, University of Ulm, for his help in viewing the histological sections.

\section{References}

1. Caspary, W. F. (1974), Eur. J. Clin. Invest. 4, 17-24.

2. Faust, R. G. \& S. L. Wu (1965), J. Cell Comp. Physiol. 65, 435-448.

3. Forth, W., Rummel, W. \& Glasner, H. (1966), Nauny.nSchmiedebergs Arch. Pharmakol. Exp. Pathol. 254, 364380.

4. Feldman, E. B., Watt, R. \& Feldman, D. S. (1975), Clin. Res. 23, 46A.

5. Frizzell, $\vec{R}$. A. \& Schultz, S. G. (1970), Biochim. Biophys. Acta 211, 589-592.

6. Gracey, M., Burke, V. \& Oshin, A. (1971), Biochim. Biophys. Acta 225, 308-314.

7. Gracey, M., Burke, V. \& Oshin, A. (1971), Scand. J. Gastroenterol. 6, 273-276.

8. Harries, J. T. \& Sladen, G. E. (1972), Gut 13, 596-603.

9. Lukie, B. E., Westergaard, H. \& Dietschy, J. M. (1974), Gastroenterology 67, 652-661.

10. Parkinson, T. M. \& Olson, J. A. (1963), Life Sci. 6, 393-398.

11. Faust, R. G. (1963), Fed. Proc. 22, 226.

12. Dawson, A. M. \& Isselbacher, K. J. (1959), J. Clin. Invest. 39, 730-740.

13. Pope, J. L., Parkinson, T. M. \& Olson, J. A. (1966), Biochim. Biophys. Acta 130, 218-232.

14. Sladen, G. E. \& Harries, J. T. (1972), Biochim. Biophys. Acta 288, 443-456.

15. Tomkin, G. H. \& Love, A. H. G. (1972), Digestion 6, 129-138. 
16. Wingate, D. L. (1973), J. Physiol. 229, 43P-44P.

17. Wingate, D. L. (1973), J. Physiol. 230, 63P-65P.

18. Saunders, D. R. (1975), J. Physiol. 250, 373-383.

19. Wingate, D. L., Phillips, S. F. \& Hofmann, A. F. (1973), J. Clin. Invest. 52, 1230-1236.

20. Krag, E. \& Phillips, S. F. (1974), J. Lab. Clin. Med. 83, 947-956.

21. Böhmer, R. (1972), in: Bile acids in human diseases (Back, P. \& W. Gerok, eds.) 259-261, F. K. Schattauer Verlag, Stuttgart-New York.

22. Herberg, R. J. (1965), Packard Technical Bulletin 15, 1-8.

23. Schmidt, F. H. (1961), Klin. Wochenschr. 39, 1244-1247.

24. Henry, R. J., Cannon, D. C. \& Winkelman, J. W. (1974), Clinical Chemistry, 2nd ed., 1550-1551, Harper \& Row, Hagerstown.

25. Heinold, J. \& Gaede, K. W. (1972), Ingenieur-Statistik S. 274, Oldenburg Verlag München-Wien.

26. Pfanzagl, J. (1972), Allgemeine Methodenlehre der Statistik II, Sammlung Göschen, Verlag Walter de Gruyter \& Co, Berlin-New York.

27. Böhmer, R. (1976), Habilitation Ulm, FRG.

28. Dietschy, J. M. (1967), Fed. Proc. 26, 1589-1598.
29. Rampone, A. J. (1970), Proc. Soc. Exp, Biol. Med. 135, 666-670.

30. Spaeth, D. G. \& D. L. Schneider (1974), Proc. Söc. Exp. Biol. Med. 147, 855-858.

31. Sigrist-Nelson, K. \& Hopfer; U. (1974), Biochim. Biophys. Acta 367, 247-254.

32. Gray, G. M. (1971), Ann. Rev. Med., 391-404.

33. Dahlqvist, A. (1970), Enzymol. Biol. Clin. 11, 52-66.

34. Maroux, S., Lợvàrd, D. \& Desnuelle, P. (1975), Proceedings of the Tenth FEBS Meeting, 55-69.

35. Maroux, S. \& Louvard, D. (1976), Biochim. Biophys. Acta $419,189-195$.

36. Dahlquist, A. \& Thomson, D. L. (1963), J. Physiol. 167, 193-209.

37. Gray, G. M. \& Isselbacher, F. J. (1965), J. Clin. Invest. 44, $390-398$

38. Teem, M. V. \& Phillips, S. F. (1972); Gastroenterology 62 , $261-267$.

39. Keeling, J. W., Lamabadusuriya, S. P. \& Harries, J. R. (1976), J. Pathol. 118, 157-163.

40. Tsang, H. L., Teichberg, S., Wapnir, R. A. \& Lifshitz, F. (1976), Gastroenterology 70, A85/943.

PD Dr. R. Böhmer 1. Medizinische Abteilung Márienkrankenhaus

Alfredstraße 9

D-2000 Hamburg 76 